\title{
Appointment and removal of judges and assignment of files at Civil Courts in Kenya - current issues
}

\author{
By: Naomi Gichuki*
}

\section{A. Introduction}

Appointment of judges is a fundamental aspect in securing the independence of the judiciary, which is expected to be free from any form of interference, whether direct or indirect. Freedom of judges has a close relationship with judicial appointment because the appointment system has a direct bearing on the impartiality, integrity and independence of judges. ${ }^{1}$ Since the judiciary exercises powers that affect the lives and liberties of individual citizens, a well-functioning judiciary is necessary in order to uphold principles of rule of law and ensure protection of fundamental rights. In constituting judicial power, two potentially opposing needs must be balanced; the need to ensure that the judiciary is independent of executive interference and undue pressure from other sources, and the need to maintain the responsiveness, professional standards and personal integrity required of any judiciary. ${ }^{2}$

Before Kenya's current constitution was passed into law in 2010, the role of the judiciary in maintaining a democratic and just society had been severely eroded in many ways. The previous constitutional dispensations allowed the President to single handedly appoint the Chief Justice, the Attorney General and Judges of the High Court and Court of Appeal. Majority of the members of the Judicial Service Commission were also presidential appointees. The resulting effect was that a lot of judicial decisions from the $80 \mathrm{~s}$ and $90 \mathrm{~s}$ were progovernment. The judiciary failed to uphold its mandate of being the custodian of rule of law, human rights and fundamental freedoms, and was itself considered an obstacle to constitutional reform. ${ }^{3}$ Comprehensive constitutional reform was needed in order to restore public confidence in governance institutions, particularly the judiciary, which suffered extremely negative public perception following the catastrophic general elections of 2007. The effect of the 2010 constitution was a massive change in the judiciary, and most notably in the process of appointment and removal of judges.

* The author is a doctoral candidate at the Tanzanian German Centre for Eastern African Legal Studies (TGCL) sponsored by the DAAD, and based at the University of Dar es Salaam School of Law. Her research focus is on the Extractives Industry in East Africa. Naomi can be reached through gichukinyambura@gmail.com.

1 Akkas Sarkar. Appointment of Judges: A Key Issue of Judicial Independence. 2004. Bond Law Review, Volume 16 Issue 2.

2 Institute for Democracy and Electoral Assistance. Judicial Appointments.

3 In 2002, a section of judicial officers sought judicial review orders to stop the discussion and adoption of provisions relating to the judiciary in the draft constitution, claiming that judges would be adversely affected by the proposals. 


\section{B. Appointment and Removal of Judges}

The appointment and removal of judges in Kenya is established under Chapter Ten of the Constitution of Kenya, 2010. The superior courts in Kenya presided over by judges are; the Supreme Court, the Court of Appeal, the High Court and other courts with the status of the High Court established by Parliament to hear and determine disputes relating to employment and labour relations, and environment, use, occupation of, and title to land. The procedural requirements for appointment and removal of the Chief Justice, Deputy Chief Justice and other judges are set out in the Judicial Service Act of 2011.

\section{Judicial Appointments}

The Constitution provides that the President shall appoint the Chief Justice and the Deputy Chief Justice, in accordance with the recommendation of the Judicial service Commission, and subject to the approval of the National Assembly. ${ }^{4}$ All other judges are to be appointed in accordance with the recommendation of the Judicial Service Commission. ${ }^{5}$

The Judicial Service Commission is comprised of;

a) the Chief Justice, who is the chairperson of the Commission;

b) one Supreme Court judge elected by the judges of the Supreme Court;

c) one Court of Appeal judge elected by the judges of the Court of Appeal;

d) one High Court judge and one magistrate, one a woman and one a man, elected by the members of association of judges and magistrates;

e) the Attorney-General;

f) two advocates, one woman and one man, each of whom has at least 15 years' experience, elected by the members of the statutory body responsible for the professional regulation of advocates;

g) one person nominated by the Public Service Commission; and

h) one woman and one man to represent the public, not being lawyers, appointed by the President with the approval of the National Assembly.

The Chief Registrar of the Judiciary, who is the chief administrator and accounting officer of the judiciary, ${ }^{6}$ acts as the secretary of the Commission. ${ }^{7}$ 


\section{Requirements for Appointment}

The Constitution provides that each judge of a superior court shall be appointed from among persons who- ${ }^{8}$

a) Hold a law degree from a recognized university, or are advocates of the High Court of Kenya, or possess an equivalent qualification in a common-law jurisdiction;

b) Have a high moral character, integrity and impartiality

Specific requirements for the positions of Chief Justice, Deputy Chief Justice, Judges of the Supreme Court, and judges of the Court of Appeal are set out below.

The Chief Justice and other judges of the Supreme Court shall be appointed from among persons who have; ${ }^{9}$

a) At least fifteen years experience as a superior court judge

b) at least fifteen years' experience as a distinguished academic, judicial officer, legal practitioner or such experience in other relevant legal field; or

c) held the qualifications specified in paragraphs (a) and (b) for a period amounting, in the aggregate, to fifteen years.

Each judge of the Court of Appeal shall be appointed from among persons who have- 10

a) at least ten years' experience as a superior court judge; or

b) at least fifteen years' experience as a distinguished academic or legal practitioner or such experience in other relevant legal field; or

c) held the qualifications mentioned in paragraphs (a) and (b) for a period amounting, in the aggregate, for ten years.

Each judge of the High Court shall be appointed from among persons who have- ${ }^{11}$

a) at least ten years' experience as a superior court judge or professionally qualified magistrate; or

b) at least ten years' experience as a distinguished academic or legal practitioner or such experience in other relevant legal field; or

c) held the qualifications specified in paragraphs (a) and (b) for a period amounting, in the aggregate, to ten years.

In determining the qualifications of individual applicants for the position of Judge of any of the superior courts, the Judicial Service Commission is to be guided by the following criteria: ${ }^{12}$

8 Article 166(2.).

9 Article 166(3.).

10 Article 166(4.).

11 Article 166(5.).

12 Judicial Service Act, First Schedule, Rule 13. 
a) professional competence

b) written and oral communication skills

c) integrity

d) fairness

e) good judgment and common sense

f) legal and life experience

g) demonstrable commitment to public and community service

\section{Appointment Procedure}

The Judicial Service Commission is required to constitute a 5-member selection panel in order to ensure that the recruitment of judges is transparent. ${ }^{13}$ The panel's function is to shortlist persons for nomination by the Commission, ${ }^{14}$ in relation to appointment of the Chief Justice and the Deputy Chief Justice. ${ }^{15}$ The First Schedule of the Act sets out in greater detail, the provisions relating to the procedure for appointment of judges. The first step in the appointment process relates to vacancies and applications. This is then followed by review of the applications and background investigation, interviews and post nomination procedures.

Where a vacancy occurs or exists in the office of a judge, the chief Justice is required to place a notice to that effect in the Gazette within 14 days of the occurrence of such vacancy. The Judicial Service Commission is also required to post a notice on its own website, send notice of the vacancy to the law Society of Kenya and any other lawyers' professional associations and circulate the notice in any other appropriate manner. ${ }^{16}$ Each applicant seeking consideration for nomination and recommendation for appointment to a judicial office is required to complete and file the prescribed application form, ${ }^{17}$ which requires the applicant to provide; ${ }^{18}$

(a) background information and in particular information that may be relevant to determine qualifications for office, including but not limited to academic, employment, legal practice and judicial or financial discipline; community service, pro bono activity and non-legal interests; involvement as a party in litigation; criminal record; and residential address;

(b) references and in particular the names of three professional references and two character references who can verify the applicant's past and present employment;

13 The Judicial Service Act, 2011, Section 30(1.).

14 Section 30(2.).

15 Section 30(3.).

16 Rule 3(1.).

17 Rule 4(2.).

18 Rule 4(3.). 
(c) if in legal practice, detailed information about the applicant's practice of law within the past five years; and if engaged elsewhere, detailed information on that engagement in the last five years;

(d) a sample of any writings by the applicant which may include any legal publications the applicant has authored;

(e) a declaration of income and liabilities at the time of application; and

(f) a brief written summary of the applicant's bio-data including legal education, and legal experience.

The second step in the appointment procedure related to review of applications and conducting of background investigations. The Commission is tasked with the responsibility of reviewing applications to determine whether the applicants meet the minimum Constitutional and statutory requirements for the position. ${ }^{19}$ Before issuing a press release announcing the names of the applicants, the Commission is required to carry out reference checks within 14 days of the deadline for the receipt of applications, by communicating to all of the applicant's references and former employers and asking them to comment on the applicant's qualifications. ${ }^{20}$ Within thirty days of the reference check, the Commission shall investigate and verify the applicants' professional and personal background for information that could pose a significant problem for the proper functioning of the courts should the applicant be appointed. ${ }^{21}$ Such background investigations may continue until the Commission votes on its nominations.

Upon completion of the above checks, the Commission is to issue a press release announcing the names of the applicants on its website as well as in the Kenya Gazette. ${ }^{22}$ The Commission is also tasked at this point, with inviting members of the public to avail in writing, any information of interest to the Commission in relation to any of the applicants, and interview any member of the public that has submitted any information on any of the applicants. $^{23}$

The interview process is then carried out after candidates have been shortlisted. The Commission is required to schedule specific interview times for each applicant, and notify the applicants in writing of the date, time, and location of their interview, not less than 14 days of such interview. All interviews are carried out in public by the Commission. ${ }^{24}$ Where there is need for a member of the Commission to disclose any relevant information known or communicated to the member concerning any of the applicants, then the Commission

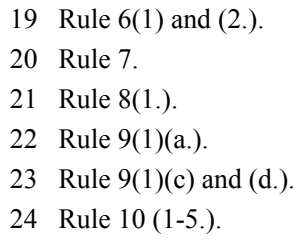


shall immediately before interviewing the applicant, briefly convene a private session to facilitate such disclosure. ${ }^{25}$

Upon seven days of the conclusion of interviews, the Commission shall deliberate and nominate the most qualified applicants taking into account gender, regional, ethnic and other diversities of the people of Kenya. The Secretary shall administer the voting and each member of the Commission shall vote based on personal assessment of the applicants' qualifications. ${ }^{26}$ The Commission's decision is then communicated to the applicants through the Secretary, within seven days of the Commission's vote. ${ }^{27}$

\section{Removal of Judges from Office}

Constitutionally, a judge of a superior court may be removed from office only on the grounds of; inability to perform the functions of office arising from mental or physical incapacity; ${ }^{28}$ a breach of a code of conduct prescribed for judges of the superior courts by an Act of Parliament; ${ }^{29}$ bankruptcy $;{ }^{30}$ incompetence; ${ }^{31}$ or gross misconduct or misbehavior. ${ }^{32}$

Removal from office is commenced upon initiation of the process by the Judicial Service Commission, acting on its own motion or upon the petition of any person to the Commission. ${ }^{33}$ Such petition to the Commission must be in writing and must set out the alleged facts constituting the grounds for the judge's removal. ${ }^{34}$

\section{Procedure for Removal from Office}

The procedure governing the conduct of a tribunal set up for purposes of removing the Chief Justice, Deputy Chief Justice of a judge shall be as set out in the Second Schedule of the Judicial Service Act. Where the Commission is satisfied that a petition for removal of a judge discloses a ground for removal, the petition shall be sent to the President. ${ }^{35}$

Upon receiving such petition, the President is required to suspend the judge from office within 14 days, and, acting on the recommendation of the Judicial Service Commission, take the following steps;

25 Rule 11

26 Rule 14 (1-3.).

27 Rule 15(1.).

28 Article 168 (1)(a.).

29 Article 168 (1)(b.).

30 Article 168 (1)(c.).

31 Article 168 (1)(d.).

32 Article 168 (1)(e.).

33 Article 168 (2.).

34 Article 168 (3.).

35 Article 168 (4.). 
a) Where the petition relates to the Chief Justice, the President shall appoint a tribunal consisting of the Speaker of the National Assembly as the chairperson; three superior court judges from common law jurisdictions; one advocate of fifteen years standing and two other persons with experience in public affairs. ${ }^{36}$

b) Where the petition relates to a judge other than the Chief Justice, the President shall appoint a tribunal consisting of; a chairperson and three members from among persons who hold or have held office as a judge of a superior court, or who are qualified to be appointed as such but who, in either case, have not been members of the Judicial Service Commission at any time within the immediately preceding three years; one advocate of fifteen years standing and two other persons with experience in public affairs. ${ }^{37}$

Any tribunals constituted as described above are required to inquire into the matter expeditiously and report on the facts, then make binding recommendations to the President. ${ }^{38}$

\section{Assignment of Files at Civil Courts in Kenya}

Kenya follows a common law system. Courts are basically at two levels namely, the superior courts and subordinate courts, both of which are established in chapter ten of the Constitution. ${ }^{39}$ Allocation of files in civil courts is dependent on the nature of the matter in question as well as the jurisdiction of the courts. The court system comprises;

a) The Supreme Court

b) The Court of Appeal

c) The High Court

d) The Industrial Court

e) The Environment and Land Court

f) The Subordinate Courts comprised of the Magistrates Courts, Kadhis' Courts, Courts Martial and any other court or local tribunal established by an Act of Parliament.

\section{Jurisdiction of Superior Courts}

The Supreme Court shall have exclusive jurisdiction to hear and determine disputes relating to the elections to the office of President, and appellate jurisdiction to hear and determine appeals from the Court of Appeal, and any other court or tribunal as prescribed by national legislation. ${ }^{40}$ The Court of Appeal has jurisdiction to hear appeals from the High Court, and any other court or tribunal as prescribed by an Act of Parliament. ${ }^{41}$ The High Court has un-

37 Article 168 (5) (b.).

38 Article 168 (8.).

39 Article 162 (1-4.).

40 Article 163 (3)(a) and (b.).

41 Article 164(3)(a) and (b.). 
limited jurisdiction in criminal and civil matters; jurisdiction to determine the question whether a right or fundamental freedom in the Bill of Rights has been denied, violated, infringed or threatened; jurisdiction to hear an appeal from a decision of a tribunal appointed under the Constitution to consider the removal of a person from office, other than a tribunal established to remove a president on grounds of incapacity; jurisdiction to hear any question respecting the interpretation of the Constitution and any other jurisdiction, original or appellate, conferred on it by legislation. ${ }^{42}$ The High Court also has supervisory jurisdiction over the subordinate courts and over any person, body or authority exercising a judicial or quasi-judicial function, but not over a superior court. ${ }^{43}$

The High Court is further divided into 9 different divisions, which have been established over time in order to facilitate effective case management and expeditious disposal of cases. Further, the divisions were created in order to have similar disputes effectively and efficiently adjudicated before these specialized divisions. The High Court at Nairobi has the following divisions; the criminal division, civil division, the constitutional and human rights division, the judicial review division, land and environment law division, commercial and tax division, the family division, the Anti-Corruption and Economic Crimes Division and the Admiralty division (in Mombasa).

\section{Jurisdiction of Subordinate Courts}

The Jurisdiction of Magistrates Courts is set out in the Magistrate Courts Act of 2015 which provides that a magistrate's court shall have and exercise such jurisdiction and powers in proceedings of a civil nature in which the value of the subject matter does not exceed- 44

a) twenty million shillings (200,000USD), where the court is presided over by a chief magistrate

b) fifteen million shillings (165,000USD) where the court is presided over by a senior principal magistrate;

c) ten million shillings $(110,000 \mathrm{USD})$ where the court is presided over by a principal magistrate

d) seven million shillings $(77,000 \mathrm{USD})$ where the court is presided over by a principal magistrate

e) five million shillings $(55,000 \mathrm{USD})$ where the court is presided over by a resident magistrate

In proceedings of a civil nature, magistrate's courts also have jurisdiction in certain matters under African customary law including matters concerning land held under customary tenure; marriage, divorce, maintenance or dowry; guardianship, custody, adoption or legiti-

42 Article 165 (3) (a-e.).

43 Article 165 (6.).

44 Section 7(1.). 
macy of children and intestate succession and administration of intestate estates so far as they are not governed by any written law. ${ }^{45}$

\section{Allocation of Files in Civil Courts}

All processes in the High Court and Magistrates Civil Courts are governed by the Civil Procedure Act, Cap 21, and the rules thereof, save for the jurisdiction which is set out in the Constitution and other Acts of Parliament as earlier highlighted. This paper will only discuss processes pertaining to allocation of files in civil courts. Civil cases include; contract and tenancies; tort in all its forms; miscellaneous civil applications (arising out of taxation, registration of foreign judgments and arbitration awards, applications for presumption of death, applications for leave to appeal out of time, applications for transfer of cases from magistrates courts and registration of applications for pauperism); appeals from subordinate Courts and tribunals and disputes related to leadership in churches, sports associations, professional bodies and clubs.

Each division of the High Court has its own registry. Subordinate courts also have registries for civil and criminal matters respectively, especially in smaller court stations where civil and criminal courts share the same premises or building. However, all registries share common processes and steps from the time of filing the matter to the point at which the matter is heard and concluded by the respective court. These common processes include registration, filing, court fees assessment, service of court process, fixing of hearing dates, cause listing and records management.

Allocation commences at the registry, with the preliminary stage involving filing and verification of documents before the matter is formally registered and assigned to a court. The filing stage entails presentation of pleadings at the registry, verification of the pleadings, assessment of court fees, verification of court fees deposit slip, assignment of a case number, issuance of court fees receipt by the cashier, date stamping of the documents, registration of the case, entry of data in the case register and entry of data in the case management system. Once this is done, summons are issued, signed by the Deputy Registrar or Registry Supervisor, and then sealed with the Seal of the Court on the day of filing the suit. Summons is then issued by the Court within 30 days from the date of filing.

The next stage is that of fixing hearing dates. Courts are to fix matters for hearing and serve hearing notices on advocates or parties, with priority being given to older matters. Advocates and parties in person can also take hearing dates after issuing invitation letters, which must be brought to the registry one week in advance in order to allow sufficient time to retrieve the required files. Court Registry Assistants are required to confirm service and ensure that a matter is ready for hearing before issuing a date. Cause lists are prepared by the respective registries one week in advance and are classified into hearings, mentions, applications, notice to show cause, submissions, rulings and judgments. 


\section{Conclusion and Way Forward}

The appointment of Judges in Kenya has come a long way from the days when judges were exclusively presidential appointees to the current system where the process is not only widely inclusive of a wide array of stakeholders, but is also transparent and credible. This is not to say however, that challenges are absent. In the recent case of Trusted Society of Human Rights v the Judicial Service Commission, the Petitioner's case was that the JSC had enumerated qualifications outside the constitution including clearance from HELB, ${ }^{46}$ KRA, ${ }^{47}$ and the Ethics and Anti-Corruption Commission. It was argued that the Commission's decision to provide for additional qualifications for positions violated the constitution, was ultra vires and should be quashed. They put forth that determination of independence of judiciary is not based on one event but the whole process starting from the manner of appointment.

The court held that the inclusion of extraneous matters in the advertisement does not warrant quashing of the advertisement. The decision of the JSC to summarily reject applicants before the interview stage was unsupported by law and tainted with procedural irregularity. As such, the decision of the JSC rejecting some of the names of the applicants was quashed. The JSC was also compelled by court to reconsider the applicants and proceed according to the law. The JSC was also prohibited from making recommendations to the President on the persons to be appointed as the Chief Justice, Deputy Chief justice, and Judge of the Supreme Court pending its reconsideration.

For a long time, litigation in Kenya was plagued with massive backlog across all courts. In order to ease the tension and pressure on superior courts, the Magistrate Courts Act was revised in order to significantly raise the pecuniary jurisdiction of the magistrates' courts. It remains to be seen whether the impact of this move will be commensurate to the expected reduction of case pile-up.

All in all, the journey towards creating a transparent appointment procedure has come a long way, and the outcome has seen renewed public confidence in the judicial arm of government. As seen through the Trusted Society Case highlighted above, the appointment process is still relatively new and is slowly being carved out to be fully aligned with the procedures and requirements set out by the law.

46 Higher Education Loans Board.

47 Kenya Revenue Authority. 


\section{BIBLIOGRAPHY}

1. Akkas Sarkar. Appointment of Judges: A Key Issue of Judicial Independence. 2004. Bond Law Review, Volume 16 Issue 2.

2. Institute for Democracy and Electoral Assistance. Judicial Appointments.

3. The Constitution of Kenya, 2010

4. The Judicial Service Act, 2011

5. The Magistrates Courts Act 